\title{
PR-10, defensin and cold dehydrin genes are among those over expressed in Oxytropis (Fabaceae) species adapted to the arctic
}

\author{
Annie Archambault • Martina V. Strömvik
}

Received: 17 November 2010 /Revised: 25 March 2011 / Accepted: 3 April 2011 /Published online: 17 April 2011

(C) The Author(s) 2011. This article is published with open access at Springerlink.com

\begin{abstract}
In many studied plants, typical responses to cold treatment include up-regulating the hydrophilic COR/LEA genes and down-regulating photosynthesis-related genes, carbohydrate metabolism, GDSL-motif lipase, hormone metabolism and oxidative regulation genes. However, next to nothing is known about gene expression in arctic plants, which are actually adapted to a harsh, cold environment. The molecular mechanisms behind the many specific adaptations of arctic plants, such as slow growth, welldeveloped root systems and short stature, are not well understood. In this study, we examine whole plantlet transcriptome differences between two arctic and two temperate Oxytropis (Fabaceae) species, grown under their respective controlled environmental conditions. Gene expression differences are analyzed using cDNA library subtraction followed by expressed sequence tags sequencing and annotation. Sequences from a total of nearly 2,000 clones cluster into 121 and 368 unique genes from the arctic and from the temperate plants, respectively. The predominant biological process for genes from the arcticenriched library is "response to stimulus". A concurrent overexpression of pathogenesis-related class 10 proteins (PR-10), plant defensin and cold dehydrin genes is a novel feature for species adapted to stressful growth environment. The temperate-enriched genes are involved in photosynthe-
\end{abstract}

Electronic supplementary material The online version of this article (doi:10.1007/s10142-011-0223-6) contains supplementary material, which is available to authorized users.

A. Archambault $\cdot$ M. V. Strömvik $(\square)$

Department of Plant Science, Macdonald Campus,

McGill University,

21111 Lakeshore Road,

Sainte Anne de Bellevue, QC H9X 3V9, Canada

e-mail: martina.stromvik@mcgill.ca

URL: http://www.mcgill.ca/plant/faculty/stromvik/ sis, translation and nucleosome assembly. Interestingly, both arctic and temperate-enriched libraries also contain genes involved in ribosome biogenesis and assembly, however of different types. Real-time reverse transcription PCR of cold dehydrin and two PR-10 genes, as well as the light harvesting complex b1 genes demonstrates that the gene expression is dependent on species and growth conditions.

Keywords Arctic · Plant - Gene expression · Oxytropis · Library subtraction $\cdot$ Defence response
Abbreviations
ADR6 Auxin down-regulated 6
BLAST Basic local alignment search tool
cDNA Complimentary DNA
ESTs Expressed Sequence Tags
ELIP Early Light Induced proteins
LEA Late Embryogenesis Abundant proteins
mRNA Messenger RNA
PCR Polymerase Chain Reaction
PDF1 Plant Defensin 1
PR-10 Pathogenesis-Related class 10 proteins
RT-PCR Reverse Transcription PCR
SSH Suppressive subtraction hybridization
STP Specific tissue protein

\section{Introduction}

The challenges to arctic plant life go beyond the severe winter cold temperatures - very short growing season, common summer frosts, strong winds and low light quality are limiting conditions to plant growth. These tough little 
plants present a suite of morphological and physiological specializations compared to their temperate relatives. They have long life cycles (Grulke and Bliss 1988), leaves or flower primordium development extend on for many growth seasons (Sørensen 1941) and they sport welldeveloped root systems (Bliss and Gold 1999). Furthermore, their photosynthetic and respiratory apparatus is more efficient at $10^{\circ} \mathrm{C}$ than at higher temperatures (Xiong et al. 1999; Semikhatova et al. 2007; Pyankov 1991), and they can tolerate freezing temperatures while still actively growing (Junttila and Robberecht 1993). However, the understanding of the molecular mechanisms behind these adaptations is at best fragmentary.

Because of the potential adaptive value of variation in gene expression (Swindell et al. 2007; Whitehead and Crawford 2006a, b), we explored differentially expressed genes between arctic and temperate plants. We chose the Oxytropis (Fabaceae) genus as our model system. Oxytropis is predominantly distributed in the temperate and boreal regions of North America and Northern Asia, and also includes 44 arctic species (Elven 2007). Although only eight species occur in the Canadian Arctic, this is the legume genus with highest species diversity in that area (Aiken et al. 2007). We used the suppression subtractive hybridization ( $\mathrm{SSH}$ ) technique to discover differences in the transcriptomes of two arctic Oxytropis species and two temperate Oxytropis species. Because it is an untargeted approach that enables novel gene discovery, the subtraction technique is especially appropriate for characterizing molecular features underlying the suite of arctic plant specializations. Expression of selected genes was validated by real-time reverse transcription polymerase chain reaction (PCR). The study is the first of its kind and we present several important differences in gene expression between the species.

\section{Materials and methods}

\section{Plant material and RNA extractions}

Seeds of the arctic species Oxytropis maydelliana and Oxytropis arctobia and the temperate species Oxytropis splendens and Oxytropis campestris subsp. johannensis were scarified, sterilized and stratified at $4^{\circ} \mathrm{C}$ on $1 / 2 \mathrm{MS}$ Basal Medium (Sigma, Oakville, Ontario) agar plates. The seed sources are listed in Supplementary Table S1. Germinating seeds were placed in growth chambers mimicking the summer-fall conditions in temperate climates $(16 \mathrm{~h}$ of light of $225 \mu \mathrm{mol} / \mathrm{m}^{2} / \mathrm{s}$ at $22^{\circ} \mathrm{C}$ and $8 \mathrm{~h}$ of darkness at $18^{\circ} \mathrm{C}$ ) or in the low arctic $\left(20 \mathrm{~h}\right.$ of light of $150 \mu \mathrm{mol} / \mathrm{m}^{2} / \mathrm{s}$ at $10^{\circ} \mathrm{C}$ and $4 \mathrm{~h}$ of darkness at $10^{\circ} \mathrm{C}$ ). RNA was extracted (Qiagen) from plantlets at the two leaves stage.
Suppressive subtraction cDNA library construction

Extracted RNA from two plantlets of a species were pooled prior to complimentary DNA (cDNA) synthesis, and $1 \mathrm{mg}$ of this pool was used as template for cDNA synthesis using the SuperSmart PCR cDNA Synthesis kit (Clontech, Mountain View, CA). Genes specifically expressed in either the arctic or in the temperate species were isolated by applying the suppression subtractive hybridization strategy (Diatchenko et al. 1996) using the PCR-select cDNA subtraction kit (Clontech, Mountain View, CA). The subtraction compared a pool of plantlet cDNA from the two arctic species (O. arctobia and O. maydelliana) grown in simulated arctic environment, and a pool of plantlet cDNA from the two temperate species $(O$. campestris subsp. johannensis and $O$. splendens) grown in simulated temperate environment. The subtraction was performed in both directions resulting in two subtracted libraries: one "arctic-enriched" library and one "temperate-enriched" library. PCR products of arctic- and temperate-subtracted libraries were cloned non-directionally using a TOPO TA kit and transformed into ElectroMAX DH10B electro competent cells (Invitrogen, Carlsbad, California). White colonies were grown in a total of thirty 96-well plates containing SOC-ampicillin liquid medium, and subsequently screened by PCR using vector primers.

Sequence analysis and annotation of subtracted library clones

Clones with confirmed single inserts were sequenced single-pass (McGill University and Génome Québec Innovation Center). Sequences were base called using phred (Green 2002) and trimmed using SeqTrim (Falgueras et al. 2007). The sequences appear in public sequence databases under the GenBank accession numbers GW696871 to GW698115. The 1,108 arctic and 609 temperate processed expressed sequence tags (ESTs) sequences were assembled into contigs using Phrap (Green 2002) as described (Stromvik et al. 2006; Vodkin et al. 2004). Eight ESTs that appeared to be chimaeras were excluded from further analysis. Blast2GO (Conesa et al. 2005; Gotz et al. 2008) was used to annotate and to assign Gene Ontology terms (Ashburner et al. 2000) to contigs and singlets representing unique genes. Presence of potential false positives (reported in Table 1) in each subtracted library was assessed by building two local basic local alignment search tool (BLAST) target databases, and evaluating sequence similarities between the two libraries using BLASTN and TBLASTX (Altschul et al. 1997). False positives are cDNAs retrieved from a subtracted library but that are not differentially expressed. Oxytropis unique gene sequences were manually classified into general categories considering the assigned Gene Ontology terms for biological process, the 
MIPS functional categories (Ruepp et al. 2004), and the similarity (by BLASTX) to the complete Arabidopsis peptide sequence collection (TAIR8 pep_20080412). Annotations were manually verified and curated, based on information in the Kyoto Encyclopedia of Genes and Genomes (Kanehisa and Goto 2000), the Arabidopsis Information Resource (Swarbreck et al. 2008), the Plant Metabolic Network database (Zhang et al. 2005) or the NCBI Entrez Gene (Maglott et al. 2005).

\section{Real-time reverse transcription PCR}

Expression differences were confirmed for four genes with real-time reverse transcription PCR (RT-PCR) from cDNA. Specific primers (Supplementary Table S2) were designed in Geneious (Drummond et al. 2008) and manually adjusted to ensure that a primer anneals to a region that is conserved among the four species but that varies among the copies of a gene family. The different single PCR products from the four different Oxytropis genomes were sequenced and compared to other sequences of its gene family to confirm that primers pairs amplify a single gene. Plantlets from all four species (arctic and temperate) were grown from seeds in temperate and in arctic conditions (described above), RNA was extracted and $2 \mathrm{mg}$ of RNA from single plantlets were reverse transcribed into cDNA using the QuantiTect kit (Qiagen, Mississauga).

Real-time RT-PCR reactions were performed using Brilliant SYBR Green dye (Supplementary Table S2) with two technical replicates per samples for each of three biological replicates, and data were analyzed with MxP3000 4.01 software (Stratagene). Normalization was carried out relative to actin gene expression (Simon 2003). An analysis of variance (ANOVA) using the general linear model (GLM) was performed on normalized relative expression ratio followed by Student-Newman-Keuls tests (SAS Institute 2004) between species in each growth conditions, separately.

\section{Results}

EST sequencing from subtracted libraries reveals different biological processes in arctic and temperate plants

In order to characterize potential adaptive differences in gene expression, we investigated transcriptome differences between arctic and temperate Oxytropis species. One arcticenriched and one temperate-enriched subtracted library (by SSH) were constructed from Oxytropis plantlet mRNA. From the arctic-enriched library, 1,108 trimmed ESTs were assembled into 117 arctic unique genes; while from the temperate-enriched library 609 trimmed ESTs were assem- bled into 364 temperate unique genes. The compositions of the contigs are listed in Supplementary Table S3 (arctic) and S4 (temperate). The unique gene sequences were first given a putative annotation by searching similarities against public protein sequences database (Conesa et al. 2005; Gotz et al. 2008). This annotation was then manually verified, curated and assigned to general categories using several bioinformatics databases. The breakdown of the genes in functional categories is presented in Table 1, while the full list of annotated sequences are listed in Supplementary Table S3 (arctic) and S4 (temperate). Most Oxytropis unique genes received an annotation, except for $25.6 \%$ of the arctic-enriched and $7.6 \%$ of the temperate-enriched unique genes that have no similarity to any sequences in the public database. The temperate-enriched library comprises genes from a wide variety of processes and is especially rich in energy and photosynthesis related genes and in nucleosome assembly genes whereas the arctic-enriched library shows an important enrichment in "response to stimulus" and in novel genes (Table 1). Ribosomal genes of different types are present in both subtracted libraries. The results of similarity searches performed between the two libraries indicate that 21 of the 364 temperate unique genes and 19 of the 117 arctic unique genes are potential false positives.

The two subtracted libraries comprise numerous unique genes from several multigene families. Gene families retrieved from the arctic-enriched library include the pathogenesis-related class 10 proteins PR-10 (ten unique genes), defensins PDF1 (plant defensin 1; eight unique genes) and cold dehydrins (11 unique genes). Gene families retrieved from the temperate-enriched library belong to chlorophyll $\mathrm{a} / \mathrm{b}$ binding proteins (12 unique genes), lipid transfer protein LTP (five unique genes), aluminium induced response ADR6 (three unique genes), ripening related protein (seven unique genes), specific tissue protein STP (four unique genes), vegetative storage protein-like (three unique genes) and metallothionein Type 1 (three unique genes).

Real-time RT-PCR of selected genes confirms differential gene expression and identifies a potential adaption to the arctic conditions

Expression of four genes was further investigated using real-time RT-PCR for all four species (O. arctobia, $O$. campestris subsp. johannensis, $O$. maydelliana and $O$. splendens) each grown in arctic and in temperate simulated conditions (GenBank accession numbers HM107135 to HM107155; Fig. 1).

The cold dehydrin gene corresponding to arctic.contig47 (from the arctic-enriched library) is expressed in both arctic species in both the arctic and the temperate growth 
Table 1 Proportion of expressed sequence tags (ESTs) retrieved from arctic-enriched and temperate-enriched Oxytropis subtractive cDNA libraries according to general categories

\begin{tabular}{lll}
\hline Gene category & $\begin{array}{l}\text { EST ratio in arctic-enriched library } \\
\text { (potential false positive) })^{\mathrm{b}}\end{array}$ & $\begin{array}{l}\text { EST ratio in temperate-enriched library }^{\mathrm{a}} \\
\text { potential false positive) }^{\mathrm{b}}\end{array}$ \\
\hline No similarity & $5.85 \times 10^{-1}\left(5.91 \times 10^{-3}\right)$ & $5.84 \times 10^{-2}(0)$ \\
Unclassified & $3.55 \times 10^{-3}(0)$ & $2.12 \times 10^{-1}\left(1.82 \times 10^{-3}\right)$ \\
ROS related & $5.91 \times 10^{-3}\left(3.54 \times 10^{-3}\right)$ & $2.74 \times 10^{-2}\left(5.47 \times 10^{-3}\right)$ \\
Histones & $1.18 \times 10^{-3}\left(1.18 \times 10^{-3}\right)$ & $2.92 \times 10^{-2}\left(1.82 \times 10^{-3}\right)$ \\
DNA-proteins & 0 & $2.00 \times 10^{-2}(0)$ \\
RNA-proteins (ribosomes) & $2.01 \times 10^{-2}\left(9.46 \times 10^{-3}\right)$ & $7.66 \times 10^{-2}\left(3.65 \times 10^{-3}\right)$ \\
Response to stimulus & $2.31 \times 10^{-1}\left(1.19 \times 10^{-1}\right)$ & $1.08 \times 10^{-1}\left(1.28 \times 10^{-2}\right)$ \\
Secondary metabolism & 0 & $1.46 \times 10^{-2}(0)$ \\
Hormones & $4.73 \times 10^{-3}\left(4.73 \times 10^{-3}\right)$ & $3.83 \times 10^{-2}\left(7.30 \times 10^{-3}\right)$ \\
Transport & $2.36 \times 10^{-4}\left(1.18 \times 10^{-3}\right)$ & $4.01 \times 10^{-2}\left(7.3 \times 10^{-3}\right)$ \\
Nucleotides & 0 & $1.82 \times 10^{-3}(0)$ \\
Signaling & $1.18 \times 10^{-3}\left(1.18 \times 10^{-3}\right)$ & $1.82 \times 10^{-2}\left(1.82 \times 10^{-3}\right)$ \\
Protein modifications & $1.18 \times 10^{-3}(0)$ & $2.00 \times 10^{-2}(0)$ \\
Nitrogen & $1.18 \times 10^{-3}\left(1.18 \times 10^{-3}\right)$ & $2.00 \times 10^{-2}\left(5.47 \times 10^{-3}\right)$ \\
Lipid & $7.57 \times 10^{-2}\left(7.47 \times 10^{-2}\right)$ & $1.46 \times 10^{-2}\left(3.65 \times 10^{-3}\right)$ \\
Carbohydrates & $1.18 \times 10^{-3}(0)$ & $3.65 \times 10^{-2}(0)$ \\
Energy & $3.55 \times 10^{-2}\left(1.18 \times 10^{-4}\right)$ & $2.65 \times 10^{-1}\left(1.82 \times 10^{-3}\right)$ \\
\hline
\end{tabular}

$R O S$ reactive oxygen species

${ }^{a}$ The ratio of ESTs in a category is expressed relative to the total number of ESTs in the subtracted library of origin, as EST ratio=number of EST sequences in library in this category/total number of EST sequences in library

${ }^{\mathrm{b}}$ Values in parenthesis report the potential false positive, identified using similarity of unique genes from one subtracted library to the unique genes of the other subtracted library

conditions (Fig. 1a). In the temperate species, the gene is expressed twice as much in the arctic than in the temperate conditions. This cold dehydrin may therefore be constitutive in arctic species, but cold induced in temperate species.

Arctic.contig61 and arctic.contig13/36 are two paralogs of the PR-10 family (pathogen-related proteins, class 10). Both are present in the genomes of all four Oxytropis species but they have different expression patterns. $O$. arctobia expresses the arctic.contig61 gene at a very high level under arctic conditions and at a reduced level under temperate conditions (Fig. 1b). In the other arctic species (O. maydelliana), the gene is almost not expressed in either growth condition. The two temperate species express the arctic.contig61 gene under arctic conditions but not under temperate conditions. The arctic.contig13/36 gene is expressed in the $O$. maydelliana arctic species and the two temperate species at a low level in arctic but not in temperate conditions, but is not expressed at all in $O$. arctobia (Fig. 1c).

The temperate.contig119 is a light harvesting complex from photosystem I type $b$ and was retrieved from the temperate-enriched library. It is expressed in both conditions for all species, and slightly more in the temperate conditions (Fig. 1d). Expression is significantly higher in the temperate than in the arctic conditions only in $O$. splendens. The quantitative real-time RT-PCR data for these four genes provide validation of results found with the PCR-select method.

\section{Discussion}

Arctic Oxytropis plantlets exhibit a lower expression for photosynthesis related genes, typical of cold acclimation

In order to shed light on potential molecular adaptations that arctic plants have developed, we have sequenced and compared the subtracted plantlet transcriptomes of arctic and temperate Oxytropis legume species. These plants express distinct transcriptome signatures in their natural environment that shows both typical and novel features compared to latitudinal or altitudinal gradients in transcriptome variation in other plant lineages (Holliday et al. 2008; Swindell et al. 2007; Voelckel et al. 2008), or to plant species adapted to other abiotic stresses (van de Mortel et al. 2006; Lai et al. 2006; Knight et al. 2006; Hammond et al. 2006; Filatov et al. 2006; Brosche et al. 2005; Taji et al. 2004). Given that important constraints to plant growth in 
a) Cold regulated dehydrin (arctic.contig47)

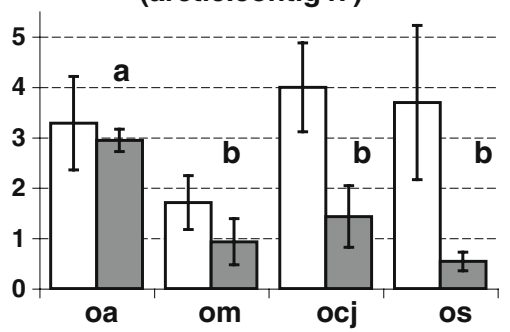

c)

PR-10 gene (arctic.contig13/36)

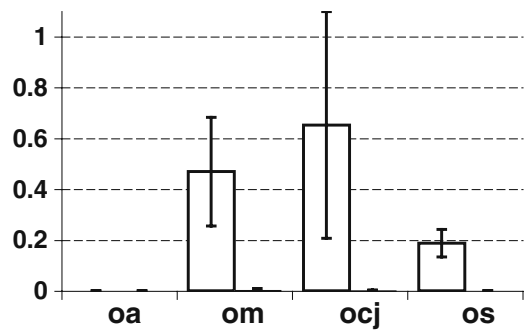

Fig. 1 Expression of selected genes compared in transcriptomes of two arctic Oxytropis species (O. arctobia and O. maydelliana) and two temperate species $(O$. campestris subsp. johannensis and $O$. splendens) under two climatic conditions. Real-time RT-PCR was used to measure gene expression in cDNA. Values on the $Y$-axis are the mean ratio of the selected gene relative to actin expression. Actin was used as a normalizing gene \pm 1 standard deviation of three biological replicates and two technical replicates. a Expression of arctic.contig47

the arctic are low summer temperature and frequent summer frosts (Savile 1972), arctic species are expected to show adequate expression of cold treatment genes. Gene expression reorganization following cold stress is now well characterized in model (Hannah et al. 2005) and agronomical (Cheng et al. 2007) plant species, and many of the differentially expressed genes between arctic and temperate Oxytropis species conform to this pattern. In Arabidopis, genes up-regulated after long-term cold exposure are mainly of the stress response category, especially the hydrophilic COR/LEA proteins (Hannah et al. 2005), and some are found in the Oxytropis arctic-enriched library.

Several genes down-regulated after long-term cold exposure in Arabidopis, such as photosynthesis-related genes, carbohydrate metabolism, GDSL-motif lipase, hormone metabolism and oxidative regulation genes (Hannah et al. 2005) are found in the Oxytropis temperate-enriched library. Expression levels of the light harvesting gene $l h c b I$ calculated by real-time RT-PCR are higher in temperate conditions for all four Oxytropis species, suggesting that expression is dependent on growth conditions. This finding is consistent with the deterioration of photosynthetic capacity following cold exposure in most plants (Savitch et al. 2001; Stitt and Hurry 2002; Walters 2005) and with a
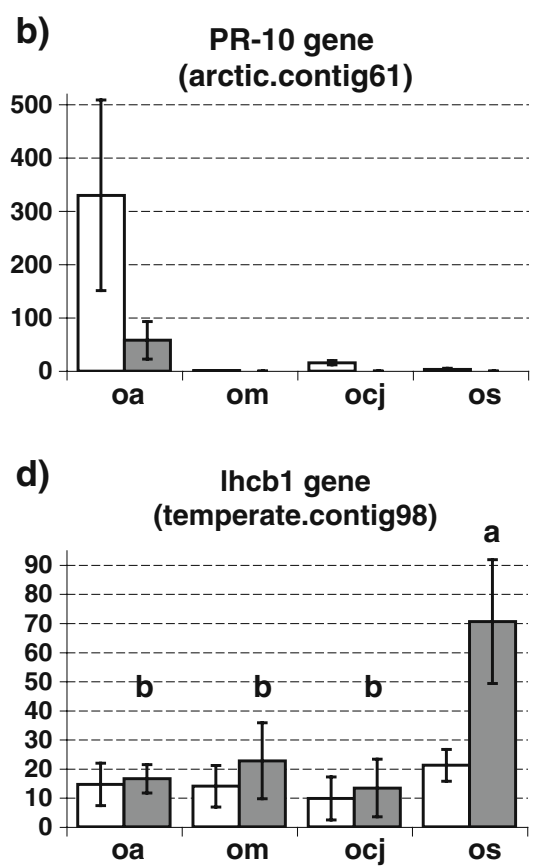

(cold dehydrin); b arctic.contig61 (PR-10); c arctic.contig13/36 (PR10 ); d temperate.contig98 (light harvesting protein I, lhcbI). Abbreviations: oa, O. arctobia; om, O. maydelliana; ocj, O. campestris subsp. johannensis; os $O$. splendens. The white bars represent expression of plantlets from the arctic conditions, and the dark grey bars from the temperate conditions. Small letters $a$ or $b$ above bars denote values that are significantly different at the 0.05 level (one-way ANOVA-GLM with SNK)

plastic response of arctic plants that modify their optimum temperature for photosynthesis and carbon integration within a few days after being placed in warmer growth conditions (Pyankov and Vaskovskii 1994).

Defence response is a prominent characteristic of the arctic plantlet transcriptome

The constraints on plant growth imposed by the arctic environment extend beyond cold temperatures, and also include very short growing season, strong winds, low light intensity but long days. It is therefore expected to see a set of expressed genes in the arctic Oxytropis plantlets unique and different from a cold-treated temperate model plant. The most striking feature of the Oxytropis arctic-enriched library is its enrichment in genes of the "response to stimulus" category, indicating that under arctic simulated growth conditions, arctic Oxytropis express more of defensin (PDF1), pathogenesis-related proteins (PR-10), cold dehydrins, early light inducible (ELIP). These four genes are not as a group typical of those up-regulated during cold acclimation in temperate plants.

In other species, stress response genes show a substantial among taxa variation in gene expression (e.g. Chen et al. 2005), 
even under optimal conditions. Genes of this category also exhibit, in favourable conditions, an elevated expression for populations or species adapted to adverse environmental conditions (Beritognolo et al. 2008; Taji et al. 2004), whether for drought (Knight et al. 2006; Brosche et al. 2005), metal (van de Mortel et al. 2006), saline (Taji et al. 2004) or subarctic growth condition (Holliday et al. 2008).

We show that the PR-10 gene family is one of the largest overrepresented in arctic Oxytropis; that different Oxytropis species express different paralogs of the PR-10 family, and that expression is greatly enhanced by cold. These results suggest that members of the PR-10 gene family may be involved in long-term adaptation to arctic adverse conditions. The $O$. arctobia plantlet expresses a different paralog of PR-10 than the other three species, which could indicate that subfunctionalization has been effective during the course of Oxytropis genome evolution, as described for groups of species comprising polyploids (Adams 2007). The original biological roles attributed to PR-10 proteins were in plant defence with antibacterial, antimicrobial (Pinto et al. 2005; Pinto and Ricardo 1995; Broderick et al. 1997) and ribonucleolytic functions (Bantignies et al. 2000), but recent evidence suggest additional functions in cold response (Goulas et al. 2007), development (Sikorski et al. 1999; Bantignies et al. 2000; Pinto et al. 2005; Iturriaga et al. 1994), hormone binding (Fernandes et al. 2008) and secondary metabolism (Liu and Ekramoddoullah 2006). Among all these functions, the ones related to pathogen response are less likely to have played a role in adaptation to the Arctic given that potential pathogens (Strathdee and Bale 1998) and fungal symbionts (Kytoviita 2005) have low diversity and abundance in that area.

Plant defensins are other "response to stimulus" genes overrepresented in the arctic Oxytropis plantlets transcriptome. Similarly to the PR-10, plant defensins (reviewed in Thomma et al. 2002) were first described as antifungal proteins (Terras 1995) but were also shown to be developmentally regulated in healthy legumes (Ishibashi et al. 1990; Hanks et al. 2005). They show a differential expression in many pairs of closely related species (Hanks et al. 2005; van de Mortel et al. 2006; Holliday et al. 2008; Hammond et al. 2006), to the favour of an increased expression in the stressadapted species or population. Defensins are abundant at seed germination and could protect from soil-borne pathogens (Carvalho and Gomes 2009; Hanks et al. 2005), which is compatible with the expression detected in very young Oxytropis plantlets. However, as for the PR-10, other biological roles, such as zinc tolerance (van de Mortel et al. 2006), regulation of the ascorbic acid redox state and even self-incompatibility (reviewed in Carvalho and Gomes 2009), may also explain the differential expression between Oxytropis species.
Cold dehydrins is another "response to stimulus" gene family largely present in the arctic Oxytropis transcriptome. A certain level of constitutive expression for cold dehydrins was described (Boudet et al. 2006), in addition to its induction by heat, cold, drought, wounding and virus infection in soybean (Takahashi and Shimosaka 1997) and in Medicago (Chen et al. 2008; Pennycooke et al. 2008). Our finding that expression of a cold dehydrin gene is less responsive to the growth conditions in the arctic species than it is in the temperate species is in agreement with reports on a less-responsive expression of "response to stimulus" genes in stress-adapted plant species, (Brosche et al. 2005; Taji et al. 2004). The proposed role of cold dehydrins in drought tolerance (Close 1996) is desirable in an environment where water is limited (Aiken et al. 2007) and where frequent summer frosts can induce ice formation in the apoplast leading to cellular dehydration.

A concurrent overexpression of the gene families PR-10, defensin and cold dehydrin, is a novel feature for plants adapted to adverse environmental conditions. Other "response to stimulus" genes are overexpressed in arctic Oxytropis, although with a less-striking expression difference, and several of these were also overexpressed in other stress tolerant species. The ELIP are overexpressed in arctic Oxytropis, a pattern described earlier (Lai et al. 2006), but that is not universal since they were also overexpressed in the lower altitude Pachycladon fastigata (Voelckel et al. 2008) or the Californian Picea (Holliday et al. 2008).

Ribosome biogenesis and assembly genes are differentially expressed between arctic and temperate species

Results from the Oxytropis library subtraction suggest a differential expression for genes involved in ribosome biogenesis and assembly of a novel and not previously described pattern for arctic plants. Since arctic Oxytropis not only overexpress but also underexpress an important set of ribosome related genes; ribosome organization might play an important role in long-term adaptation of plants to the arctic, or in specific response to arctic conditions. In other species, it has been shown that several of these genes either increase (Kim et al. 2004; Saez-Vasquez et al. 2000) or decrease in (Berberich et al. 2000; Swindell et al. 2007) expression following stresses; or are differentially regulated during development (McIntosh and Bonham-Smith 2006; Whittle and Krochko 2009). Furthermore, differential expression of ribosomal genes among other population and species has been detected (Voelckel et al. 2008; Hammond et al. 2006; Filatov et al. 2006; Holliday et al. 2008), where, as in Oxytropis, more ribosomal genes are underexpressed than overexpressed in 
the species adapted to more stressful environment. This observation could reflect the observed slower growth of arctic plants (Bliss and Gold 1999; Aiken et al. 2007) in their natural habitat.

Nucleosome assembly genes are underrepresented in the arctic transcriptome

Histone genes are overrepresented in the temperateenriched library, suggesting an underexpression in the arctic Oxytropis. Although a close look at differentially expressed genes in other plant species adapted to stressful conditions reveals anecdotic overexpression of some histone genes and underexpression of others (Filatov et al. 2006; Hammond et al. 2006; Holliday et al. 2008), we have not found examples where this category of genes is an important feature of a specialized transcriptome. In addition to the differential expression that we show here in Oxytropis for histone genes, previous findings describing that different histone genes can be differentially regulated during plant development (Huh et al. 1995) or stress response (Kapros et al. 1992) suggest that regulation of expression for genes related to chromatin assembly may also participate in plant adaptation to environmental conditions, rather than be a simple cause of slower cell division for arctic species (Meshi et al. 2000).

\section{Conclusion}

This is the first report to our knowledge on gene expression profiles of an arctic plant and our findings are supported by previous reports on plant adaptation to stressful environmental conditions. Arctic Oxytropis species, as opposed to temperate ones, over express stress response genes such as certain PR-10 genes, defensin and cold dehydrins and under express photosynthesis and histone genes. Real-time RTPCR results also show that a cold dehydrin likely participated in adaptation to the Arctic because it is constitutive in the arctic species, and cold induced in the temperate species.

Acknowledgements This work was supported by a grant from Natural Sciences and Engineering Research Council of Canada (NSERC) to MVS. AA was supported by Le Fonds québécois de la recherche sur la nature et les technologies (FQRNT), Eben-Hopson and Girardin-Vaillancourt scholarships. Field trip was made possible by Northern Scientific Training Program (NSTP) grants from the Department of Indian and Northern Affairs Canada, and by Centre Sève (FQRNT). We would like to thank Dr. Susan Aiken, Dr. Danielle Prévost, Dr. Carolyn Parker, Dr. Tracy Sterling and Plant Gene Resources of Canada (Agriculture and Agri-Food Canada, Saskatoon Research Centre) for providing Oxytropis seeds and Christine Ide for technical help.
Open Access This article is distributed under the terms of the Creative Commons Attribution Noncommercial License which permits any noncommercial use, distribution, and reproduction in any medium, provided the original author(s) and source are credited.

\section{References}

Adams K (2007) Evolution of duplicate gene expression in polyploid and hybrid plants. J Hered 98(2):136-141. doi:10.1093/jhered/es1061

Aiken S, Consaul L, Gillespie L (2007) Flora of the Canadian Arctic Archipelago. Canadian Museum of Nature and NRC Research Press, Ottawa, ISBN 9780660197272

Altschul S, Madden T, Schaffer A, Zhang J, Zhang Z, Miller W, Lipman D (1997) Gapped BLAST and PSI-BLAST: a new generation of protein database search programs. Nucleic Acids Res 25(17):3389-3402

Ashburner M, Ball C, Blake J, Botstein D, Butler H, Cherry J, Davis A, Dolinski K, Dwight S, Eppig J, Harris M, Hill D, Issel-Tarver L, Kasarskis A, Lewis S, Matese J, Richardson J, Ringwald M, Rubin G, Sherlock G (2000) Gene ontology: tool for the unification of biology. Nat Genet 25(1):25-29

Bantignies B, Seguin J, Muzac I, Dedaldechamp F, Gulick P, Ibrahim R (2000) Direct evidence for ribonucleolytic activity of a PR-10-like protein from white lupin roots. Plant Mol Biol 42(6):871-881

Berberich T, Uebeler M, Feierabend J (2000) cDNA cloning of cytoplasmic ribosomal protein $\mathrm{S} 7$ of winter rye (Secale cereale) and its expression in low-temperature-treated leaves. Biochim Biophys Acta: Gene Struct Expression 1492(1):276-279

Beritognolo I, Sabatti M, Brosche M, Scarascia Mugnozza G (2008) Functional genomics to discover genes for salt tolerance in annual and perennial plants. In: Abdelly C, Ozturk M, Ashraf M, Grignon C (eds) Biosaline agriculture and high salinity tolerance. Birkhauser Verlag, Switzerland, pp 273-286

Bliss L, Gold W (1999) Vascular plant reproduction, establishment, and growth and the effects of cryptogamic crusts within a polar desert ecosystem, Devon Island, NWT, Canada. Can J Bot-Rev Can Botanique 77(5):623-636

Boudet J, Buitink J, Hoekstra F, Rogniaux H, Larre C, Satour P, Leprince O (2006) Comparative analysis of the heat stable proteome of radicles of Medicago truncatula seeds during germination identifies late embryogenesis abundant proteins associated with desiccation tolerance. Plant Physiol 140(4):1418-1436

Broderick K, Pittock C, Arioli T, Creaser E, Weinman J, Rolfe B (1997) Pathogenesis-related proteins in Trifolium subterraneum: a general survey and subsequent characterisation of a protein inducible by ethephon and redlegged earth mite attack. Aust J Plant Physiol 24(6):819-829

Brosche M, Vinocur B, Alatalo E, Lamminmaki A, Teichmann T, Ottow E, Djilianov D, Afif D, Bogeat-Triboulot M, Altman A, Polle A, Dreyer E, Rudd S, Lars P, Auvinen P, Kangasjarvi J (2005) Gene expression and metabolite profiling of Populus euphratica growing in the Negev desert. Genome Biology 6(12):doi:10.1186/gb-2005-6-12-r101

Carvalho AD, Gomes VM (2009) Plant defensins - prospects for the biological functions and biotechnological properties. Peptides 30 (5):1007-1020. doi:10.1016/j.peptides.2009.01.018

Chen W, Chang S, Hudson M, Kwan W, Li J, Estes B, Knoll D, Shi L, Zhu T (2005) Contribution of transcriptional regulation to natural variations in Arabidopsis. Genome Biology 6(4). doi:10.1186/gb2005-6-4-r32

Chen D, Liang M, DeWald D, Weimer B, Peel M, Bugbee B, Michaelson J, Davis E, Wu Y (2008) Identification of dehydration responsive genes from two non-nodulated alfalfa cultivars using Medicago truncatula microarrays. Acta Physiologiae Plant 30(2):183-199 
Cheng C, Yun K, Ressom H, Mohanty B, Bajic V, Jia Y, Yun S, de los Reyes B (2007) An early response regulatory cluster induced by low temperature and hydrogen peroxide in seedlings of chillingtolerant japonica rice. BMC Genomics 8:175. doi:10.1186/14712164-8-175

Close T (1996) Dehydrins: emergence of a biochemical role of a family of plant dehydration proteins. Physiol Plant 97(4):795-803

Conesa A, Gotz S, Garcia-Gomez J, Terol J, Talon M, Robles M (2005) Blast2GO: a universal tool for annotation, visualization and analysis in functional genomics research. Bioinformatics 21 (18):3674-3676

Diatchenko L, Lau Y, Campbell A, Chenchik A, Moqadam F, Huang B, Lukyanov S, Lukyanov K, Gurskaya N, Sverdlov E, Siebert P (1996) Suppression subtractive hybridization: a method for generating differentially regulated or tissue-specific cDNA probes and libraries. Proc Natl Acad Sci USA 93(12):60256030

Drummond AJ, Ashton B, Cheung M, Heled J, Kearse M, Moir R, Stones-Havas S, Thierer T, Wilson A (2008) Geneious, 40th edn. Biomatters, Auckland, NZ

Elven R (2007) Checklist of the Panarctic Flora (PAF) vascular plants. Russian Foundation for Basic Research Grant N 07-04-01015-a. http://www.binran.ru/infsys/paflist/index.htm. 2008. Accessed October 2010

Falgueras J, Lara AJ, Canton FR, Perez-Trabado G, Claros MG (2007) SeqTrim - a validation and trimming tool for all purpose sequence reads. In: Corchado E, Corchado JM, Abraham A (eds) Innovations in hybrid intelligent systems, vol 44. Advances in soft computing. Springer, Berlin, pp 353-360

Fernandes H, Pasternak O, Bujacz G, Bujacz A, Sikorski M, Jaskolski M (2008) Lupinus luteus pathogenesis-related protein as a reservoir for cytokinin. J Mol Biol 378(5):1040-1051

Filatov V, Dowdle J, Smirnoff N, Ford-Lloyd B, Newbury H, Macnair M (2006) Comparison of gene expression in segregating families identifies genes and genomic regions involved in a novel adaptation, zinc hyperaccumulation. Mol Ecol 15 (10):3045-3059

Gotz S, Garcia-Gomez J, Terol J, Williams T, Nagaraj S, Nueda M, Robles M, Talon M, Dopazo J, Conesa A (2008) Highthroughput functional annotation and data mining with the Blast2GO suite. Nucleic Acids Res 36(10):3420-3435

Goulas E, Richard-Molard C, Le Dily F, Le Dantec C, Ozouf J, Ourry A (2007) A cytosolic vegetative storage protein (TrVSP) from white clover is encoded by a cold-inducible gene. Physiol Plant 129(3):567-577

Green P (2002) Phred, Phrap, and Consed. University of Washington. http://www.phrap.org/phredphrapconsed.html. 2008. Accessed October 2010

Grulke N, Bliss L (1988) Comparative life-history characteristics of two High Arctic grasses, Northwest Territories. Ecology 69 (2):484-496

Hammond J, Bowen H, White P, Mills V, Pyke K, Baker A, Whiting S, May S, Broadley M (2006) A comparison of the Thlaspi caerulescens and Thlaspi arvense shoot transcriptomes. New Phytol 170(2):239-260

Hanks J, Snyder A, Graham M, Shah R, Blaylock L, Harrison M, Shah D (2005) Defensin gene family in Medicago truncatula: structure, expression and induction by signal molecules. Plant Mol Biol 58(3):385-399

Hannah M, Heyer A, Hincha D (2005) A global survey of gene regulation during cold acclimation in Arabidopsis thaliana. PLoS Genet 1(2):179-196

Holliday J, Ralph S, White R, Bohlmann J, Aitken S (2008) Global monitoring of autumn gene expression within and among phenotypically divergent populations of Sitka spruce (Picea sitchensis). New Phytol 178(1):103-122
Huh G, Matsuura Y, Meshi T, Iwabuchi M (1995) Differential expression of the two types of histone H2A genes in wheat. Biochim Biophys Acta: Gene Struct Expression 1261(1):155-160

Ishibashi N, Yamauchi D, Minamikawa T (1990) Stored messengerRNA in cotyledons of Vigna unguilculata seeds - nucleotide sequence of cloned cDNA for a stored messenger RNA and induction of its synthesis by precocious germination. Plant Mol Biol 15(1):59-64

Iturriaga E, Leech M, Barratt D, Wang T (1994) Two ABA-responsive proteins from pea (Pisum sativum L.) are closely related to intracellular pathogenesis-related proteins. Plant Mol Biol 24 (1):235-240

Junttila O, Robberecht R (1993) The influence of season and phenology on freezing tolerance in Silene acaulis L, a sub-arctic and arctic cushion plant of circumpolar distribution. Ann Bot 71(5):423426

Kanehisa M, Goto S (2000) KEGG: Kyoto Encyclopedia of Genes and Genomes. Nucleic Acids Res 28(1):27-30

Kapros T, Bogre L, Nemeth K, Bako L, Gyorgeyey J, Wu S, Dudits D (1992) Differential expression of histone H3 gene variants during cell cycle and somatic embryogenesis in Alfalfa. Plant Physiol 98 (2):621-625

Kim K, Park S, Chung Y, Chung C, Kim J, Lee J (2004) Molecular cloning of low-temperature-inducible ribosomal proteins from soybean. J Exp Bot 55(399):1153-1155

Knight C, Vogel H, Kroymann J, Shumate A, Witsenboer H, MitchellOlds T (2006) Expression profiling and local adaptation of Boechera holboellii populations for water use efficiency across a naturally occurring water stress gradient. Mol Ecol 15(5):12291237

Kytoviita M (2005) Asymmetric symbiont adaptation to arctic conditions could explain why High Arctic plants are nonmycorrhizal. FEMS Microbiol Ecol 53(1):27-32

Lai Z, Gross B, Zou Y, Andrews J, Rieseberg L (2006) Microarray analysis reveals differential gene expression in hybrid sunflower species. Mol Ecol 15(5):1213-1227

Liu J, Ekramoddoullah A (2006) The family 10 of plant pathogenesisrelated proteins: their structure, regulation, and function in response to biotic and abiotic stresses. Physiol Mol Plant Pathol 68(1-3):3-13

Maglott D, Ostell J, Pruitt K, Tatusova T (2005) Entrez Gene: genecentered information at NCBI. Nucleic Acids Res 33:D54-D58

McIntosh K, Bonham-Smith P (2006) Ribosomal protein gene regulation: what about plants? Can J Bot-Rev Can Botanique 84(3):342-362

Meshi T, Taoka K, Iwabuchi M (2000) Regulation of histone gene expression during the cell cycle. Plant Mol Biol 43(5-6):643-657

Pennycooke J, Cheng H, Stockinger E (2008) Comparative genomic sequence and expression analyses of Medicago truncatula and alfalfa subspecies falcata COLD-ACCLIMATION-SPECIFIC genes. Plant Physiol 146(3):1242-1254. doi:10.1104/ pp.107.108779

Pinto M, Ricardo C (1995) Lupinus albus L pathogenesis-related proteins that show similarity to PR-10 proteins. Plant Physiol 109 (4):1345-1351

Pinto M, Ribeiro A, Regalado A, Rodrigues-Pousada C, Ricardo C (2005) Expression of Lupinus albus PR-10 proteins during root and leaf development. Biol Plant 49(2):187-193

Pyankov V (1991) Effect of temperature on photosynthesis and carbon metabolism in related plant species of the arctic tundra of Wrangel Island and the central Urals. Sov Plant Physiol 38 (5):607-613

Pyankov V, Vaskovskii M (1994) Temperature adaptation of the photosynthetic apparatus of tundra plants Oxyria digyna and Alopecurus alpinus from Wrangel Island. Russ J Plant Physiol 41 (4):454-461 
Ruepp A, Zollner A, Maier D, Albermann K, Hani J, Mokrejs M, Tetko I, Guldener U, Mannhaupt G, Munsterkotter M, Mewes H (2004) The FunCat, a functional annotation scheme for systematic classification of proteins from whole genomes. Nucleic Acids Res 32(18):5539-5545

Saez-Vasquez J, Gallois P, Delseny M (2000) Accumulation and nuclear targeting of $\mathrm{BnC24}$, a Brassica napus ribosomal protein corresponding to a mRNA accumulating in response to cold treatment. Plant Sci 156(1):35-46

SAS Institute (2004) SAS/STAT ${ }^{\circledR}$ 9.1. 9.1 edn., Cary, NC, USA

Savile DBO (1972) Arctic adaptations in plants. Canada Department of Agriculture Monograph no. 6. Canada Department of Agriculture, Ottawa

Savitch L, Barker-Astrom J, Ivanov A, Hurry V, Oquist G, Huner N, Gardestrom P (2001) Cold acclimation of Arabidopsis thaliana results in incomplete recovery of photosynthetic capacity, associated with an increased reduction of the chloroplast stroma. Planta 214(2):295-303

Semikhatova O, Ivanova T, Kirpichnikova O (2007) Comparative study of dark respiration in plants inhabiting arctic (Wrangel Island) and temperate climate zones. Russ J Plant Physiol 54 (5):582-588

Sikorski M, Biesiadka J, Kasperska A, Kopcinska J, Lotocka B, Golinowski W, Legocki A (1999) Expression of genes encoding PR10 class pathogenesis-related proteins is inhibited in yellow lupine root nodules. Plant Sci 149(2):125-137

Simon P (2003) Q-Gene: processing quantitative real-time RT-PCR data. Bioinformatics 19(11):1439-1440

Sørensen T (1941) Temperature relations and phenology of the northeast Greenland flowering plants. Medd Grønland 125 (9): $1-305$

Stitt M, Hurry V (2002) A plant for all seasons: alterations in photosynthetic carbon metabolism during cold acclimation in Arabidopsis. Curr Opin Plant Biol 5(3):199-206

Strathdee A, Bale J (1998) Life on the edge: insect ecology in arctic environments. Annu Rev Entomol 43:85-106

Stromvik M, Latour F, Archambault A, Vodkin L (2006) Identification and phylogenetic analysis of sequences of Bean pod mottle virus, Soybean mosaic virus, and Cowpea chlorotic mottle virus in expressed sequence tag data from soybean. Can J Plant PatholRevue Canadienne de Phytopathologie 28(2):289-301

Swarbreck D, Wilks C, Lamesch P, Berardini T, Garcia-Hernandez M, Foerster H, Li D, Meyer T, Muller R, Ploetz L, Radenbaugh A, Singh S, Swing V, Tissier C, Zhang P, Huala E (2008) The Arabidopsis Information Resource (TAIR): gene structure and function annotation. Nucleic Acids Res 36:D1009-D1014

Swindell W, Huebner M, Weber A (2007) Plastic and adaptive gene expression patterns associated with temperature stress in Arabidopsis thaliana. Heredity 99(2):143-150
Taji T, Seki M, Satou M, Sakurai T, Kobayashi M, Ishiyama K, Narusaka Y, Narusaka M, Zhu J, Shinozaki K (2004) Comparative genomics in salt tolerance between Arabidopsis and Arabidopsis-related halophyte salt cress using Arabidopsis microarray. Plant Physiol 135(3):1697-1709. doi:10.1104/ pp.104.039909

Takahashi R, Shimosaka E (1997) cDNA sequence analysis and expression of two cold-regulated genes in soybean. Plant Sci 123 $(1-2): 93-104$

Terras FRG (1995) Small cysteine-rich antifungal proteins from radish: their role in host defense. Plant Cell 7(5):573-588

Thomma B, Cammue B, Thevissen K (2002) Plant defensins. Planta 216(2):193-202

van de Mortel J, Villanueva L, Schat H, Kwekkeboom J, Coughlan S, Moerland P, van Themaat E, Koornneef M, Aarts M (2006) Large expression differences in genes for iron and zinc homeostasis, stress response, and lignin biosynthesis distinguish roots of Arabidopsis thaliana and the related metal hyperaccumulator Thlaspi caerulescens. Plant Physiol 142(3):1127-1147

Vodkin L, Khanna A, Shealy R, Clough S, Gonzalez D, Philip R, Zabala G, Thibaud-Nissen F, Sidarous M, Stromvik M, Shoop E, Schmidt C, Retzel E, Erpelding J, Shoemaker R, RodriguezHuete A, Polacco J, Coryell V, Keim P, Gong G, Liu L, Pardinas J, Schweitzer P (2004) Microarrays for global expression constructed with a low redundancy set of 27,500 sequenced cDNAs representing an array of developmental stages and physiological conditions of the soybean plant. BMC Genomics 5:73. doi:10.1186/1471-2164-5-73

Voelckel C, Heenan P, Janssen B, Reichelt M, Ford K, Hofmann R, Lockhart P (2008) Transcriptional and biochemical signatures of divergence in natural populations of two species of New Zealand alpine Pachycladon. Mol Ecol 17(21):4740-4753

Walters R (2005) Towards an understanding of photosynthetic acclimation. J Exp Bot 56(411):435-447. doi:10.1093/jxb/eri060

Whitehead A, Crawford D (2006a) Neutral and adaptive variation in gene expression. Proc Natl Acad Sci USA 103(14):5425-5430

Whitehead A, Crawford D (2006b) Variation within and among species in gene expression: raw material for evolution. Mol Ecol 15(5): 1197-1211

Whittle C, Krochko J (2009) Transcript profiling provides evidence of functional divergence and expression networks among ribosomal protein gene paralogs in Brassica napus. Plant Cell 21(8):22032219. doi:10.1105/tpc. 109.068411

Xiong F, Ruhland C, Day T (1999) Photosynthetic temperature response of the Antarctic vascular plants Colobanthus quitensis and Deschampsia antarctica. Physiol Plant 106(3):276-286

Zhang P, Foerster H, Tissier C, Mueller L, Paley S, Karp P, Rhee S (2005) MetaCyc and AraCyc. Metabolic pathway databases for plant research. Plant Physiology 138(1):27-37 